\title{
Hyperhomoysteinemia as a risk factor for coronary heart diseases in chronic hepatitis $\mathrm{C}$ patients
}

\author{
Ali Raza Kazmi ${ }^{1}$, Andleeb Hanif ${ }^{1,2}$, Muhammad Ismail ${ }^{1}$, Javaria Qazi ${ }^{2}$ \\ ${ }^{1}$ Institute of Biomedical and Genetic Engineering, Islamabad, Pakistan \\ ${ }^{2}$ Department of Biotechnology, Quaid-i-Azam University, Islamabad, Pakistan \\ Email: drsakazmi@gmail.com
}

Received 20 August 2013; revised 28 September 2013; accepted 15 October 2013

Copyright (C) 2013 Ali Raza Kazmi et al. This is an open access article distributed under the Creative Commons Attribution License, which permits unrestricted use, distribution, and reproduction in any medium, provided the original work is properly cited.

\begin{abstract}
Hepatitis $\mathrm{C}$ virus is one of the major health problems worldwide. It affects mainly the liver but several extrahepatic manifestations are also accounted. Chronic hepatitis $\mathrm{C}$ patients are at an increased risk of developing hepatic steatosis, which share many clinical features with the metabolic syndrome. Hepatic steatosis has also been associated with elevated levels of markers of inflammation such as homocysteine, identified as hyperhomocysteinemia (HHC). HHC due to Methylenetetrahydrofolate Reductase (MTHFR) gene, in particular the C677T polymorphism, was recently associated with coronary heart diseases (CHD) in chronic hepatitis $\mathrm{C}$ (CHC) patients. Homocysteine is an intermediate in methionine metabolism, which takes place mainly in the liver metabolism. Deficiencies of micronutrients (folate, vitamin B 6 and possibly vitamin B 12) along with mild hyperhomocysteinemia, perhaps, act synergistically with other classical risk factors to further increase the risk of CHD. Clinical data indicate that HHC is associated with an increased incidence of CHD as well as with the severity of the disease in CHC patients. In conclusion, HHC might be a potential aetiological factor of $\mathrm{CHD}$ in CHC patients. The aim of this review is to investigate the progression of coronary heart diseases in chronic hepatitis $C$ patients and correlate with levels of homocysteine in concurrence to genetic defects and nutrient deficiencies. However, future studies need to clarify the mechanistic role of HHC in CHD and CHC as a useful paradigm with most interesting therapeutic implications.
\end{abstract}

Keywords: Hepatitis C Virus; Hyperhomocysteinemia (HHC); Coronary Heart Diseases (CHD); Chronic Hepatitis C (CHC)

\section{INTRODUCTION}

Chronic infection with hepatitis $\mathrm{C}$ virus (HCV) is one of the leading causes of chronic liver disease; about 170 million people worldwide are estimated to be infected. Hepatitis $\mathrm{C}$ virus infection causes acute symptoms in only $15 \%$ of patients exposed to $\mathrm{HCV}$ infection while about $80 \%$ patients develop chronic infection [1]. Chronic hepatitis $\mathrm{C}$ results in formation of high levels of free radicals in the liver cells, which put serious oxidative stress depleting protective antioxidants and eventually kill the liver cells. A hepatitis screen is recommended for patients whereby the disease can be diagnosed by the presence of antibodies for hepatitis $\mathrm{C}$ or by the direct presence of the virus or viral products in the blood [2].

\section{ASSOCIATED RISKS: CHRONIC HEPATITIS C}

Hepatitis $\mathrm{C}$ virus (HCV) infection is a major cause of chronic liver disease. HCV infection frequently does not resolve, leading to chronic hepatitis with increasing risk of developing hepatic fibrosis, steatosis, liver cirrhosis, hepatocellular carcinoma, metabolic syndromes, arthrosclerosis and extrahepatic diseases [3]. The combination of pegylated interferon (IFN)-a and ribavirin is the only treatment for chronic $\mathrm{HCV}$ infections with proven efficacy.

Unfortunately, this therapeutic strategy results in a low sustained virologic response (SVR), defined as an absence of detectable serum HCV-RNA at six months after completion of antiviral therapy; SVR is achieved in less than $50 \%$ of treated patients that have HCV genotype 1 and a high viral load [4]. There is evidence indicating that SVR is associated with long-term clearance of HCV infection and lower HCV-related complications $[5,6]$. However, IFN-a in combination with ribavirin is generally not well tolerated, and the adverse side effects may 
lead to interruption or cessation of therapy. The major adverse effects are anemia, fatigue, hair loss, depression, insomnia, vertigo, anorexia, nausea, nasal congestion, cough, dyspnea, pruritus, and growth delay [7].

\section{HEPATITIS C VIRUS AND CARDIAC RISK}

Chronic hepatitis $\mathrm{C}$ virus (CH-C) infection is associated with metabolic conditions such as insulin resistance and type 2 diabetes (T2DM) and may increase the risk of coronary heart diseases. Coronary artery disease is the most common heart disease with multifactorial etiology. Atherosclerosis being the principal cause has plagued human kind since ancient times. Its understanding has much evolved over centuries, traditionally being viewed as degenerative disease, is now considered a dynamic inflammatory and fibroproliferative process, triggered by cytokines and growth factors [8-12]. In addition to other conventional atherogenic risk factors (Age, Sex, Smoking, Hypertension, Diabetes Mellitus and Dyslipidaemia), one of the most interesting development in the recent years has been the idea that infective agents may induce a pro-inflammatory state and have a crucial role in atherothrombosis [12-14].

\section{INADEQUATE VITAMINS AND HCV}

Patients with chronic $\mathrm{HCV}$ infection have significantly lowered plasma vitamin B1, B2, B6, C, and folic acid levels [15]. These patients were also observed to have significantly higher plasma homocysteine (a sulfur-containing amino acid, which is influenced by vitamin B2, 6 , 12 , and folic acid) concentrations and lower concentrations of folic acid and vitamin B12 [16]. The plasma homocysteine levels were inversely correlated with the concentrations of folic acid in HCV-infected patients. SVR patients have been observed to have lower plasma homocysteine levels than non-SVR patients [17]. Pre-treatment with IFN-a and ribavirin in chronic HCV-infected patients, serum vitamin B12 levels are positively correlated to end-of-treatment response [18].

Several infectious etiologies for coronary heart diseases (CHD) have been proposed in recent years on the basis of epidemiological associations, but there is no consensus regarding a causative role [19-21]. The association between hepatitis $\mathrm{C}$ virus (HCV) infection and $\mathrm{CHD}$ is less clear. A small number of reported studies have shown conflicting results; some have reported no association between HCV infection and CHD [22-25], whereas others have reported an increased risk [26] or an increase in measures of subclinical atherosclerosis (e.g., carotid intima-media thickness) [26-28]. Many of the studies showing no association between HCV infection and CHD used a case-control design in which subjects with known CHD were compared with control subjects without $\mathrm{CHD}$ and the prevalence of $\mathrm{HCV}$ infection was compared between the 2 groups without adjustment for all Coronary artery diseases (CAD) risk factors. However, Persons with HCV infection are at an increased risk of developing hepatic steatosis, which shares many clinical features with the metabolic syndrome [29,30]. Hepatic steatosis has also been associated with elevated levels of markers of inflammation and endothelial dysfunction [31]. Hepatitis $\mathrm{C}$ virus increases the risk of coronary artery disease, a large American study published in the Clinical Infectious Diseases [32]. These factors suggest a biologically plausible mechanism of increased risk of CHD in at least a subset of HCV-infected persons.

The main rationale of this review is shown in Figure 1.

\section{HOMOCYSTEINE METABOLISM}

Homocysteine (Hcy) belongs to a group of molecules known as cellular thiols. It is considered a "bad thiol" because its association with a variety of health conditions including cardiovascular disease, [33] end-stage renal disease, [34] neural tube defects, [35]. Recently, homocysteine has also been implicated in the pathogenesis of alcoholic liver injury [36].

The 5,10-methylenetetrahydrofolate reductase (MTHFR) is a key enzyme in the folate cycle and contributes to the metabolism of the amino-acid homocysteine. It irreversibly catalyzes the reduction of 5,10-methylene-tetrahydrofolate to 5-methyltetrahydrofolate, the major circulatory form of folate in the body and a carbon donor for conversion of homocysteine to methionine, precursor of S-adenosyl-L-methionine [37].

\section{HOMOCYSTEINE AND CHRONIC HEPATITIS C}

Homocysteine levels are also altered in chronic liver disease. Homocysteine is a sulphur containing amino acid belonging to the group of intracellular thiols. Numerous

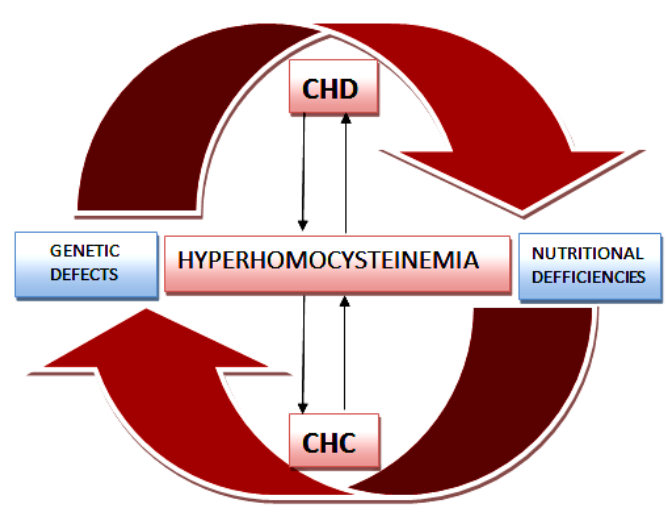

Figure 1. Rationale of study. 
clinical and epidemiological studies have reported that elevated plasma homocysteine concentrations reflect impaired cellular metabolism [38] and may be considered as an independent risk factor for atherosclerotic vascular disease and thromboembolism [39]. Experimental data in transgenic mice deficient in homocysteine metabolism enzymes have shown the presence of severe liver steatosis with occasional steatohepatitis. In human beings, many studies have found a correlation between homocysteine and steatosis [40]

Homocysteine is mainly synthesized and metabolized in the liver, since metabolism of majority of dietary methionine occurs in this organ, where about $85 \%$ of the whole body capacity for transmethylation resides. Therefore, genes involved in methionine and homocysteine metabolism are expressed in a specific pattern in the liver [41]. Homocysteine is formed as an intermediate in methionine metabolism; therefore, impaired liver function leads to altered methionine and homocysteine metabolism [42]. Plasma homocysteine levels were significantly elevated in HCV infected patients in both sexes compared with control values. These findings are in accordance with the results of many studies observed elevated plasma homocysteine levels in patients with liver cirrhosis secondary to hepatitis C virus infection [38]. Some of the studies have attributed this condition to reduced expression of genes involved in Hcy metabolism. The degree of reduced expression of these genes was related to the severity of liver disease [40].

Alterations in Hcy metabolism in human liver cirrhosis can be ascribed in part to a marked reduction in the expression of the main genes involved in its metabolism, namely methionine synthase (MS) and betaine-homocysteine methyltransferase (BHMT), which convert homocysteine back to methionine, and cystathionine-synthase (CBS), the first enzyme in the transsulfuration pathway[41]. The expression of these genes was always more compromised than that of HSA and was related to the severity of the disease, expressed as the Child-Pugh score. We observe reduced expression of Hcymetabolizing genes, both in alcoholism and hepatitis $\mathrm{C}$ virus cirrhosis. It has been suggested that impairment of Hcy metabolism in cirrhosis most possibly can be also related to decreased availability or utilization of vitamins B6, B12, or folates, [43].

\section{HYPERHOMOCYSTEINEMIA}

Elevated levels of homocysteine, Hyperhomocysteinemia (HHC), may result from defects in homocysteine-metabolizing genes; (such as MTHFR, Methylene tetrahydrofolate Reductase gene) vitamin B6, B12, or folate deficiencies resulting from nutritional conditions; or chronic alcohol consumption [40]. The hyperhomocysteinemia is known as atherogenic and thrombotic risk factor for cardiovascular disease. It might also be a risk factor for cirrhotic patients but the direct effect of Hcy on liver injury is not well known [44].

Hyperhomosysteinemia was correlated with elevated levels of ALT, ALP, TGs and cholesterol. This might be related to progression of liver injury. Some other studies have also reported a correlated elevation of plasma Hcy levels with ALT, ALP, TGs and cholesterol $[45,46]$. It is evident that homocysteine-induced endoplasmic reticulum stress leaves a dysregulated endogenous sterol response pathway, which leads to increased hepatic biosynthesis and uptake of cholesterol and triglycerides [47].

\section{GENETIC DEFECTS IN HOMOCYSTEIN METABOLISM}

Elevations in plasma homocyst(e)ine are typically caused either by genetic defects in the enzymes involved in homocysteine metabolism or by nutritional deficiencies in vitamin cofactors. Homocystinuria and severe hyperhomocyst(e)inemia are caused by rare inborn errors of metabolism resulting in marked elevations of plasma and urine homocyst(e)ine concentrations. Cystathionine $b$ synthase deficiency is the most common genetic cause of severe hyperhomocyst(e)inemia. The homozygous form of this disease - congenital homocystinuria - can be associated with plasma homocyst(e)ine concentrations of up to $400 \mathrm{mmol}$ per liter during fasting [48]. The homozygous trait is rare (occurring in 1 in 200,000 births), and clinical manifestations include ectopialentis, skeletal deformities, mental retardation, thromboembolism, and severe, premature atherosclerosis [49]. Atherothrombotic complications frequently develop in young adulthood in homozygotes and are often fatal, as first shown in a study by Carey and colleagues as early as 1968 [49]. Mudd and colleagues [50] have estimated that approximately 50 percent of untreated patients with homocystinuria will have a thromboembolic event before the age of 30 and that overall, the disease-related mortality is approximately 20 percent.

Heterozygotes typically have much less marked hyperhomocyst(e)inemia, with plasma homocyst(e)ine concentrations in the range of 20 to $40 \mathrm{mmol}$ per liter, approximately two to four times greater than the normal concentration of homocyst(e)ine in plasma [49,51-53]. A homozygous deficiency of N5, N10-methylenetetra hydrofolatereductase, the enzyme involved in the vitamin B12-dependent remethylation of homocysteine to methionine, may also lead to severe hyperhomocyst(e)inemia [54]. Patients with this type of deficiency tend to have a worse prognosis than those with cystathionine $b$-synthase deficiency, in part because of the complete lack of effective therapy $[55,56]$. In addition, studies (Kang and colleagues) [57] have reported a thermolabile 
variant of N5, N10-methylene-tetrahydrofolate reductase that is caused by a point mutation (MTHFR_C677T) in the coding region for the $\mathrm{N} 5, \mathrm{~N} \mathrm{10-methylene-tetrahy-}$ drofolate binding site, leading to the substitution of valine for alanine [58].

\section{MTHFR: $\mathrm{C} \rightarrow$ T POLYMORPHISM}

A single nucleotide polymorphism (SNP) in the MTHFR gene, which is located in the chromosome 1p36.3, has been identified. A C-to-T transition at the nucleotide 677 (C677T) in exon four results in an alanine to valine exchange which affects the catalytic domain of the enzyme; as a consequence, a thermo-labile variant of MTHFR, called t-MTHFR, is synthesized, which possesses reduced enzyme activity [59].

One of the most common mutations, or polymorphisms, that are associated with a mild increase in plasma homocysteine (hyperhomocysteinemia) is the $677 \mathrm{C} \rightarrow \mathrm{T}$ substitution (an alanine to valine change) in the enzyme methylenetetrahydrofolate reductase (MTHFR). The MTHFR is an enzyme of the folate metabolism that reduces 5,10-metilenetetraidrofolate $(5,10$-mTHFR) to 5-metiltetraidrofolate (5-mTHF), an important co-factor to homocysteine (Hcy) methylation. Mutations in MTHFR gene like C677T result in amino acids substitutions that lead to a decreased enzyme activity $[60,61]$. As a consequence of the MTHFR dysfunctions, an increased Hcy level in plasma has been expected which, in turn, produces a cytotoxic effect [62].

\section{CONCLUSION}

Hepatitis C virus infection is a major cause of progressive liver damage whose long term sequelae includes cirrhosis and primary hepatocellular carcinoma. HCV mainly affects the liver, but several tissues outside the liver have been reported to be involved, resulting in a wide spectrum of extrahepatic manifestations. Despite having fewer risk factors for cardiovascular disease, the hepatitis C-infected individuals were more likely to have been diagnosed with coronary artery disease. Multiple prospective and case-control studies have shown that a moderately elevated plasma homocysteine concentration is an independent risk factor for atherothrombotic vascular disease. Homocysteine concentrations are consistently higher in patients with peripheral, cerebrovascular, and coronary artery disease than in those without such diseases. Homocyst(e)ine promotes atherothrombogenesis by a variety of mechanisms; however, it is not yet clear whether homocysteine itself or a related metabolite or cofactor is primarily responsible for the atherothrombogenic effects of hyperhomocyst (e)inemia in vivo. However, it is biologically plausible that hepatitis $\mathrm{C}$ may increase the risk of disease such as heart attack and stoke as hepatitis steatosis (fatty liver), a common complication of hepatitis $\mathrm{C}$ infection, has been associated with increased levels of homocysteine and metabolic syndrome. Though, the reason(s) and mechanism(s) of this association need further study."

\section{ACKNOWLEDGEMENTS}

We are thankful to the head of Department of Biotechnology, Quaid-iAzam University, Islamabad, Pakistan for support.

\section{REFERENCES}

[1] National Institutes of Health Consensus Development Conference Panel statement Management of hepatitis C. (1997) Hepatology, 26, 2S-10S.

[2] Wilkins, T., Malcolm, J.K., Raina, D., Schade, R.R. Hepatitis, C: Diagnosis and treatment. (2010) American Family Physician, 81, 1351-1357.

[3] Choi, J., Ou, J.H.J. (2006) Mechanisms of liver injury. III. Oxidative stress in the pathogenesis of hepatitis $\mathrm{C}$ virus. American Journal of Physiology-Gastrointestinal \& Liver Physiology, 290, G847-G851.

http://dx.doi.org/10.1152/ajpgi.00522.2005

[4] Ghany, M.G., Strader, D.B., Thomas, D.L., Seeff, L.B. (2009) Diagnosis, management, and treatment of hepatitis C: An update. Hepatology, 49, 1335-1374.

http://dx.doi.org/10.1002/hep.22759

[5] Ghany, M.G., Nelson, D.R., Strader, D.B., Thomas, D.L., Seeff, L.B. (2011) An Update on Treatment of Genotype 1 Chronic Hepatitis C Virus Infection: 2011 Practice Guideline by the American Association for the Study of Liver Diseases. Hepatology, 54, 1433-1444. http://dx.doi.org/10.1002/hep.24641

[6] Pearlman, B.L., Traub, N. (2011) Sustained virologic response to antiviral therapy for chronic hepatitis $\mathrm{C}$ virus infection: A cure and so much more. Clinical Infectious Diseases, 52, 889-900.

http://dx.doi.org/10.1093/cid/cir076

[7] Ko, W.S., Guo, C.H., Hsu, G.S.W., Chiou, Y.L., Yeh, M.S., Yaun, S.R. (2005) Effects of zinc supplementation on the treatment of chronic hepatitis $\mathrm{C}$ patients with interferon and ribavirin. Clinical Biochemistry, 38, 614-620. http://dx.doi.org/10.1016/j.clinbiochem.2005.04.003

[8] Anton, E., Becker, M.D., Becker A.E. et al. The atherosclerosis from Egyptian mummies to immune mediated intraplaque inflammation. Dialogue in Cardiovascular Medicine, 2006, 11, 116.

[9] Becker, A.E., Boer, O.J., Wal, A.C. The role of inflamemation and infections in coronary artery disease. Annual Review of Medicine, 2001, 52, 289-297.

http://dx.doi.org/10.1146/annurev.med.52.1.289

[10] Libby, P., Hanssson, G.K. et al involvement of immune system in human atherogenesis, current knowledge and unanswered questions. Laboratory Investigation, 1991, 64, 52-50.

[11] Wal, A.C., Becker, A.E., Loos, C.M., et al. fibrous and lipid rich plaques. Plaques are part of interchangeable 
morphologies related inflammation a concept. Coronary Artery Disease, 1994, 5, 463-469.

[12] Wal, A.C., Becker A.E., Loos C.M., et al. Site of intimal rupture or erosion of thrombosed coronary atherosclerosis plaque is characterized by an inflammatory process irespective of the dominant plaque morphology. Circulation, 1994, 89, 36-44.

[13] Shah P.K. Link between infection and atherosclerosis. Who are the culprits: viruses, bacteria, both or neither? Circulation, 2001, 103, 5-6. http://dx.doi.org/10.1161/01.CIR.103.1.5

[14] Chiu, B., Viira, E., Tucker, W. and Fong I.W. (1997) Chalamydia pneumoniae, cytomegalo virus, and herpes simplex virus in atherosclerosis artery. Circulation, 96, 2144-2148. http://dx.doi.org/10.1161/01.CIR.96.7.2144

[15] Lin, C.C. and Yin, M.C. (2009) Vitamins B depletion, lower iron status and decreased antioxidative defense in patients with chronic hepatitis $\mathrm{C}$ treated by pegylated interferon alfa and ribavirin. Clinical Nutrition, 28, 34-38. http://dx.doi.org/10.1016/i.clnu.2008.09.003

[16] Roca, B., Bennasar, M., Ferrero, J.A., Monte, del M.C. and Resino, E. (2012) Hepatitis C virus co-infection and sexual risk behaviour are associated with a high homocysteine serum level in HIVinfected patients. Swiss Medical Weekly, 141, w13323.

[17] Borgia, G., Gentile, I., Fortunato, G., Borrelli, F., Borelli, S., Caterina, de M., et al. (2009) Homocysteine levels and sustained virological response to pegylated-interferon alpha $2 \mathrm{~b}$ plus ribavirin therapy for chronic hepatitis $\mathrm{C}$ : A prospective study. Liver International, 29, 248-452. http://dx.doi.org/10.1111/j.1478-3231.2008.01832.x

[18] Rosenberg, P. and Hagen, K. (2011) Serum B12 levels predict response to treatment with interferon and ribavirin in patients with chronic HCV infection. Journal of Viral Hepatitis, 18, 129-134.

http://dx.doi.org/10.1111/j.1365-2893.2010.01288.x

[19] Danesh, J., Collins, R. and Peto, R. (1997) Chronic infections and coronary heart disease: Is there a link? Lancet, 350, 430-436.

http://dx.doi.org/10.1016/S0140-6736(97)03079-1

[20] Sheehan, J., Kearney, P.M., Sullivan, S.O., Mongan, C., Kelly, E. and Perry, I.J. (2005) Acute coronary syndrome and chronic infection in the Cork coronary care casecontrol study. Heart, 91, 19-22. http://dx.doi.org/10.1136/hrt.2003.031799

[21] Fong, I.W. (2000) Emerging relations between infectious diseases and coronary artery disease and atherosclerosis. CMAJ, 163, 49-56.

[22] Arcari, C.M., Nelson, K.E., Netski, D.M., Nieto, F.J. and Gaydos, C.A. (2006) No association between hepatitis C virus seropositivity and acute myocardial infarction. Clinical Infectious Diseases, 43, e53-e56. http://dx.doi.org/10.1086/507031

[23] Volzke, H., Schwahn, C., Wolff, B., et al. (2004) Hepatitis $\mathrm{B}$ and $\mathrm{C}$ virus infection and the risk of atherosclerosis in a general population. Atherosclerosis, 174, 99-103. http://dx.doi.org/10.1016/j.atherosclerosis.2004.01.010

[24] Momiyama Y., Ohmori R., Kato R., Taniguchi H., Na- kamura H. and Ohsuzu F. (2005) Lack of any association between persistent hepatitis $\mathrm{B}$ or $\mathrm{C}$ virus infection and coronary artery disease. Atherosclerosis, 181, 211-213. http://dx.doi.org/10.1016/j.atherosclerosis.2005.02.027

[25] Tong, D.Y., Wang, X.H., Xu, C.F., Yang, Y.Z. and Xiong, S.D. (2005) Hepatitis B virus infection and coronary atherosclerosis: results from a population with relatively high prevalence of hepatitis B virus. World Journal of Gastroenterology, 11, 1292-1296.

[26] Vassalle, C., Masini, S., Bianchi, F. and Zucchelli, G.C. (2004) Evidence for association between hepatitis C virus seropositivity and coronary artery disease. Heart, 90, 565-566. http://dx.doi.org/10.1136/hrt.2003.018937

[27] Ishizaka, N., Ishizaka, Y., Takahashi, E., et al. (2002) Association between hepatitis $\mathrm{C}$ virus seropositivity, carotid-artery plaque, and intima-media thickening. Lancet, 359, 133-135.

http://dx.doi.org/10.1016/S0140-6736(02)07339-7

[28] Sawayama, Y., Okada, K., Maeda, S., Ohnishi, H., Furusyo, N. and Hayashi, J. (2006) Both hepatitis C virus and Chlamydia pneumoniae infection are related to the progression of carotid atherosclerosis in patients undergoing lipid lowering therapy. Fukuoka Igaku Zasshi, 97, 245-255.

[29] Sanyal, A.J., Contos, M.J., Sterling, R.K., et al. (2003) Nonalcoholic fatty liver disease in patients with hepatitis $\mathrm{C}$ is associated with features of the metabolic syndrome. The American Journal of Gastroenterology, 98, 20642071.http://dx.doi.org/10.1111/j.1572-0241.2003.07640.x

[30] Sanyal, A.J. (2005) Review article: Non-alcoholic fatty liver disease and hepatitis C-risk factors and clinical implications. Alimentary Pharmacology \& Therapeutics, 22, 48-51. http://dx.doi.org/10.1111/j.1365-2036.2005.02596.x

[31] Targher, G., Bertolini, L., Scala, L., Zoppini, G., Zenari, L. and Falezza, G. (2005) Nonalcoholic hepatic steatosis and its relation to increased plasma biomarkers of inflammation and endothelial dysfunction in non-diabetic men: Role of visceral adipose tissue. Diabetic Medicine, 22, 1354- 1358. http://dx.doi.org/10.1111/j.1464-5491.2005.01646.x

[32] Butt, A.A., Xiaoqiang, W., Budoff, M., Leaf, D., Kuller, L.H. and Justice, A.C. (2009) Hepatitis C virus infection and the risk of coronary disease. Clinical Infectious Diseases, 49, 225-232.

[33] Refsun, H., Ueland, P., Nygard, O. and Vollset, S.E. (1998) Homocysteine and cardiovascular disease. Annual Review of Medicine, 49, 31-36.

http://dx.doi.org/10.1146/annurev.med.49.1.31

[34] Bostom, A.G and Lathrop, L. (1997) Hyperhomocysteinemia in end-stage renal disease: Prevalence, etiology, and potential relationship to arteriosclerosis outcomes. Kidney International, 52, 10-20. http://dx.doi.org/10.1038/ki.1997.298

[35] Eskes, T.K.A.B. (1998) Open or closed? A word of differences: A history of homocysteine research. Nutrition Reviews, 56, 236-244. http://dx.doi.org/10.1111/j.1753-4887.1998.tb01755.x

[36] Ji, C. and Kaplowitz, N. (2003) Betaine decreases hy- 
peryhomocysteinemia, endoplasmic reticulum stress, and liver injury in alcohol-fed mice. Gastroenterology, 124, 1488-1499. http://dx.doi.org/10.1016/S0016-5085(03)00276-2

[37] Miner, S.E., Evrovski, J. and Cole, D.E. (1997) Clinical chemistry and molecular biology of homocysteine metabolism: An update. Clinical Biochemistry, 30, 189-201. http://dx.doi.org/10.1016/S0009-9120(96)00172-5

[38] Taha, K., El-Shayeb, A., Shafeh, R., Deghady, A. and Eldin, S.Z. (2009) Clinical significance of plasma homocysteine concentration in chronic hepatitis $\mathrm{C}$ patients with liver cirrhosis. Alexandria Journal of Medicine, 45, 755760.

[39] Roblin, X., Pofelski, J. and Zarski, J.P. (2007) Steatosis, chronic hepatitis virus $\mathrm{C}$ infection and homocysteine. Gastroentérologie Clinique et Biologique, 31, 415-720. http://dx.doi.org/10.1016/S0399-8320(07)89402-4

[40] García-Tevijano, E.R., Berasain, C., Rodríguez, J.A., Corrales, F.J., Arias, R., Martín-Duce, A., Caballería, J., Mato, J.M. and Avila, M.A. (2001) Hyperhomocysteinemia in liver cirrhosis: Mechanisms and role in vascular and hepatic fibrosis. Hypertension, 38, 1217-1221. http://dx.doi.org/10.1161/hy1101.099499

[41] Finkelstein, J.D. (2003) Methionine metabolism in liver diseases. The American Journal of Clinical Nutrition, 77, 1094-1095.

[42] Avila, M.A., Berasain, C. and Torres, L. (2000) Reduced mRNA abundance of the main enzymes involved in methionine metabolism in human liver cirrhosis and hepatocellular carcinoma. Journal of Hepatology, 33, 907-914. http://dx.doi.org/10.1016/S0168-8278(00)80122-1

[43] Lambert, D., Benhayoun, S., Adjalla, C., Gelot, M.M., Renkes, P., Gerard, P., Felden, F., Belleville, F., Gaucher, P., Guéant, J.L. and Nicolas, J.P. (1997) Alcoholic cirrhosis and cobalamin metabolism. Digestion, 58, 64-71. http://dx.doi.org/10.1159/000201425

[44] Halifeoglu, I., Gur, B. and Aydin, S. (2004) Plasma trace elements, vitamin B12, folate and homocysteine levels in cirrhotic patients compared to controls. Biochemistry, 69, 693-696.

[45] Gulsen, M., Yesilova, Z., Bagci, S., Uygun, A., Ozcan, A., Ercin, C.N., Erdil, A., Sanisoglu, S.Y., Cakir, E., Ates, Y., Erbil, M.K., Karaeren, N. and Dagalp, K. (2005) Elevated plasma homocysteine concentrations as a predictor of steatohepatitis in patients with non-alcoholic fatty liver disease. Journal of Gastroenterology and Hepatology, 20, 1448-1455.

[46] Jaeckel, E., Cornberg, M., Wedemeyer, H., Santantonio, T., Mayer, J., Zankel, H., Dietrich, M., Trautwein, C. and Manns, M.P. (2001) Treatment of acute hepatitis C with interferon alfa-2b. The New England Journal of Medicine, 345, 1452-1457. http://dx.doi.org/10.1056/NEJMoa011232

[47] Werstuck, G.H., Lentz, S.R. and Dayal, S. (2001) Homocysteine-induced endoplasmic reticulum stress causes dysregulation of the cholesterol and triglyceride biosynthetic pathways. The Journal of Clinical Investigation, 107, 1263-1267. http://dx.doi.org/10.1172/JCI11596

[48] Mudd, S.H., Levy, H.L. and Skovby, F. (1995) Disorders of transsulfuration. In: Scriver, C.R., Beaudet, A.L., Sly, W.S. and Valle, D., Eds., The metabolic and molecular bases of inherited disease, Vol. 1, McGraw-Hill, New York, 1279-1327.

[49] Carey, M.C., Donovan, D.E., FitzGerald, O. and McAuley, F.D. (1968) Homocystinuria: A clinical and pathological study of nine subjects in six families. The American Journal of Medicine, 45, 7-25. http://dx.doi.org/10.1016/0002-9343(68)90003-X

[50] Mudd, S.H., Skovby, F., Levy, H.L., et al. (1985) The natural history of homocystinuria due to cystathionine b-synthase deficiency. The American Journal of Human Genetics, 37, 1-31.

[51] Malinow, M.R., Kang, S.S., Taylor, L.M., et al. (1989) Prevalence of hyperhomocyst(e)inemia in patients with peripheral arterial occlusive disease. Circulation, 79, 1180-1188. http://dx.doi.org/10.1161/01.CIR.79.6.1180

[52] Coull, B.M., Malinow, M.R., Beamer, N., Sexton, G., Nordt, F. and de Garmo, P. (1990) Elevated plasma homocyst(e)ine concentration as a possible independent risk factor for stroke. Stroke, 21, 572-576. http://dx.doi.org/10.1161/01.STR.21.4.572

[53] Malinow, M.R., Sexton, G., Averbuch, M., Grossman, M., Wilson, O. and Upson, B. (1990) Homocyst(e)ine in daily practice: Levels in coronary heart disease. Coronary Artery Disease, 2, 4-12.

[54] Mudd, S.H., Uhlendorf, B.W., Freeman, J.M., Finkelstein, J.D. and Shih, V.E. (1972) Homocystinuria associated with decreased methylenetetrahydrofolate reductase activity. Biochemical and Biophysical Research Communications, 46, 905-912.

http://dx.doi.org/10.1016/S0006-291X(72)80227-4

[55] Erbe, R.W. (1986) Inborn errors of folate metabolism. In: Blakely, R.L. and Whitehead, V.M., Eds., Folate and pterins: Nutritional, pharmacological, and physiological aspects. Marcel Dekker, New York, 413-425.

[56] D'Angelo, A. and Selhub, J. (1997) Homocysteine and thrombotic disease. Blood, 90, 1-11.

[57] Kang, S.S., Zhou, J., Wong, P.W.K., Kowalisyn, J. and Strokosch, G. (1988) Intermediate homocysteinemia: A thermolabile variant of methylenetetrahydrofolate reducetase. The American Journal of Human Genetics, 43, 414421.

[58] Frosst, P., Blom, H.J., Milos, R., et al. (1995) A candidate genetic risk factor for vascular disease: A common mutation in methylenetetrahydrofolate reductase. Nature Genetics, 10, 111-113. http://dx.doi.org/10.1038/ng0595-111

[59] Frosst, P., Blom, H.J., Milos, R., Goyette, P., Sheppard, C.A., Matthews, R.G., Boers, G.J., den Heijer, M., Kluijtmans, L.A., van den Heuvel, L.P. and Rozen, R. (1995) A candidate genetic risk factor for vascular disease: A common mutation in methylenetetrahydrofolate reductase. Nature Genetics, 10, 111-113. http://dx.doi.org/10.1038/ng0595-111

[60] Goyette, P., Sumner, J.S., Milos, R., Duncan, A.M., Rosenblatt, D.S., Matthews, R.G. and Rozen, R. (1994) Human methylenetetrahydro folate reductase: Isolation of cDNA, mapping and mutation identification. Nature Ge- 
netics, 7, 195-200. http://dx.doi.org/10.1038/ng0694-195

[61] Put van der, N.M.J., Gabreels, F., Stevens, E.M., Smeitink, J.A., Trijbels, F.J., Eskes, T.K., van den Heuvel, L.P. and Blom, H.J. (1998) A second common mutation in the methylenetetrahydrofolate reductase gene: An additional risk factor for neural-tube defects? The American Journal of Human Genetics, 62, 1044-1051. http://dx.doi.org/10.1086/301825

[62] Andreassi, M.G., Botto, N., Battaglia, D., Antonioli, E., Masetti, S., Manfredi, S., Colombo, M.G., Biagini, A. and Clerico, A. (2003) Methylenetetrahydro folate reductase gene C677T polymorphism, homocysteine, vitamin $\mathrm{B} 12$, and DNA damage in coronary artery disease. $\mathrm{Hu}$ man Genetics, 112, 171-177. 